\title{
Comparing COVID-19-linked neurological complications with other viral infections
}

\author{
Xiao Deng, Yew-Long Lo and Eng -King Tan ${ }^{*}$
}

Keywords: COVID-19, SARS, Influenza, Cerebrovascular disease

There are increasing reports of multi-system involvement in coronavirus disease 2019 (COVID-19). Among these, cerebrovascular diseases (CVD) in COVID patients have been highlighted to be associated with varied features and prognosis. COVID-19 may possess the similar mechanism and clinical characteristics as SARS, as the viruses causing them are under the same category and share highly homological genetic sequence. Influenza H1N1 and COVID-19 are comparable in terms of outbreak size as Influenza H1N1 also bring about global pandemic. However, to date, a detailed systematic comparison of neurological complications among COVID-19, SARSCoV-1 and Influenza H1N1 infections has not been carried out.

To address this gap in knowledge, we compared the frequency, presentation and prognosis of neurological complications in COVID-19 with SARS and Influenza H1N1 infection (Tables 1, 2). This may provide further mechanistic insights into potential differences between COVID-19 and other viral infections.

We searched PubMed from January, 2020 to June, 2020. The following key words were included: "COVID-19", "SARS", "influenza", "cerebrovascular disease", "neurological symptoms", "neurological manifestations". Two review authors (EK-T, XD) independently reviewed the included studies and extracted study characteristics.

About 3\% of COVID-19 patients reported acute CVD in a study from Wuhan [1], comparable to the reported frequency of $2.42 \%$ for SARS reported in Singapore [2].

*Correspondence: gnrtek@sgh.com.sg

Department of Neurology, National Neuroscience Institute, Duke NUS Medical School, Singapore General Hospital, Outram Road, Singapore 169608, Singapore
Neurologic manifestations occurred both early and late stage in the course of the COVID-19 [3], with more clinical variability than SARS and H1N1 infections. The most common severe neurologic manifestations in COVID19 patients included acute CVD, impaired consciousness, and skeletal muscle injury, which appeared slightly higher than SARS and H1N1 patients [1, 2, 4, 5]. Acute symptomatic seizures or status epilepticus were not seen commonly in COVID-19 patients [6]. More children with H1N1 than adults suffered neurologic injury with poor outcome [7], whereas paediatric patients with COVID-19 were more likely to have better outcome than adults [8] (Table 1).

For CVD in COVID-19, we noticed that a number of them were relatively young (less than 50 years and of male gender) (Table 2). There was no consistent pattern to the types of strokes, with reports of involvement in small, medium or large vessels $[3,9]$ (Table 2). The blockages of these vessels led to infarcts and in some cases frank bleeding. The prognosis depended on the severity of the strokes at presentations and associated complications. Not surprisingly, vascular risk factors such as hyperlipidaemia, diabetes and hypertension were present especially in the older group of patients [10]. These risk factors were not different from the common stroke patients seen during non-COVID-19 period. Several patients in one series [3] have been reported to have a positive lupus anticoagulant, which may have predisposed them to the disease. However, it is not clear if these patients were more susceptible to

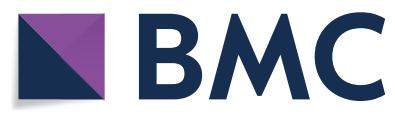

(c) The Author(s) 2020. This article is licensed under a Creative Commons Attribution 4.0 International License, which permits use, sharing, adaptation, distribution and reproduction in any medium or format, as long as you give appropriate credit to the original author(s) and the source, provide a link to the Creative Commons licence, and indicate if changes were made. The images or other third party material in this article are included in the article's Creative Commons licence, unless indicated otherwise in a credit line to the material. If material is not included in the article's Creative Commons licence and your intended use is not permitted by statutory regulation or exceeds the permitted use, you will need to obtain permission directly from the copyright holder. To view a copy of this licence, visit http://creativecommons.org/licenses/by/4.0/. The Creative Commons Public Domain Dedication waiver (http://creativecommons.org/publicdomain/zero/1.0/) applies to the data made available in this article, unless otherwise stated in a credit line to the data. 
Table 1 Severe neurological symptoms among different viral infections

\begin{tabular}{|c|c|c|c|}
\hline Neurologic disorders & $\begin{array}{l}\text { COVID-19 } \\
\text { SARS-CoV-2 infection } 2019\end{array}$ & $\begin{array}{l}\text { SARS } \\
\text { SARS-CoV-1 infection } 2003\end{array}$ & $\begin{array}{l}\text { INFLUENZA } \\
\text { H1N1 infection } 2009\end{array}$ \\
\hline Frequency & $\begin{array}{l}\text { 2.8\% (6/214) patients with acute } \\
\text { cerebrovascular disease, Wuhan } \\
\text { China [1] } \\
\text { 13.8\% (8/58) required intensive care, } \\
\text { France [13] } \\
\text { Globally, } 93 \text { patients with encepha- } \\
\text { lopathy; } 19 \text { patients with Guillain- } \\
\text { Barré syndrome; } 8 \text { cases with } \\
\text { encephalitis have been reported } \\
\text { [14] }\end{array}$ & $\begin{array}{l}\text { 2.4\% (5/206) with large-vessel } \\
\text { stroke, Singapore [2] } \\
\text { 5.3\% (4/76) with neuromuscular } \\
\text { symptoms, Taiwan [5] }\end{array}$ & $\begin{array}{l}9.1 \%(5 / 55) \text { with severe neurological } \\
\text { symptoms, Iran [4] }\end{array}$ \\
\hline Onset of Neurologic manifestations & $\begin{array}{l}\text { Can be both early and late onset of } \\
\text { neurological manifestations [3] }\end{array}$ & $\begin{array}{l}\text { Two to three weeks after the onset } \\
\text { of SARS }[2,5]\end{array}$ & Within 7 days \\
\hline $\begin{array}{l}\text { Common neurological manifesta- } \\
\text { tions in severe cases }\end{array}$ & $\begin{array}{l}\text { Impaired consciousness; Acute } \\
\text { cerebrovascular disease, Skeletal } \\
\text { muscle injury }\end{array}$ & $\begin{array}{l}\text { Polyneuropathy, encephalitis, and } \\
\text { aortic ischemic stroke }\end{array}$ & $\begin{array}{l}\text { Seizures, encephalopathy and } \\
\text { encephalitis }\end{array}$ \\
\hline Prognosis & $\begin{array}{l}\text { More patients have neurologic } \\
\text { disorders in severe subtype with } \\
\text { poor outcome }\end{array}$ & Poor & $\begin{array}{l}\text { More children than adults were } \\
\text { identified to have neurologic } \\
\text { injury with poor outcome [7] }\end{array}$ \\
\hline Possible mechanism & $\begin{array}{l}\text { The neuroinvasive potential of } \\
\text { SARS-CoV2 may play a role in the } \\
\text { respiratory failure [11] }\end{array}$ & $\begin{array}{l}\text { ACE2 [11] and immune injury may } \\
\text { play a role }\end{array}$ & $\begin{array}{l}\text { Direct infection, hypoxia and } \\
\text { metabolite dysfunction may be } \\
\text { more significant [12] }\end{array}$ \\
\hline
\end{tabular}

COVID-19 or if there was a complex interplay of the factors involved. It is possible that proinflammatory cytokines contributed to the blockage of the vessels [3]. For those stroke patients who were disabled, long term data on the final recovery outcomes were still not available.

The infection of SARS-CoV can affect brains, especially the brainstem mainly mediated by a cellular receptor angiotensin-converting enzyme 2 (ACE2) [11], which can be expressed in human airway epithelia, lung parenchyma, vascular endothelia. The similarity of severe neurological manifestations in COVID-19 and in SARS patients indicate that ACE2 may also play a role in the underlying mechanism. In addition, the respiratory failure in COVID-19 patients may result from the neuroinvasive potential of SARS-CoV2 [11]. Different from the possible mechanisms of SARS-CoV-1 and
SARS-CoV-2 infections, H1N1 infection might be due to direct infection, hypoxia and metabolite dysfunction [12].

To summarise, based on current data, the frequency of CVD in COVID-19 appeared slightly more than SARS and H1N1 patients. COVID-19 had more variability than SARS and H1N1 patients in terms of the onset of neurologic manifestations. Longitudinal studies to further clarify the chronic neurological burden could be particularly useful to stratify COVID-19 patients and guide the medical recourse allocation. It could be particularly useful to guide strategic planning for current and future pandemics. Functional studies to decipher the pathophysiologic mechanism, in particular the role of the COVID-19 in vessel wall inflammation, blockage and secondary cytokine response will be warranted. 


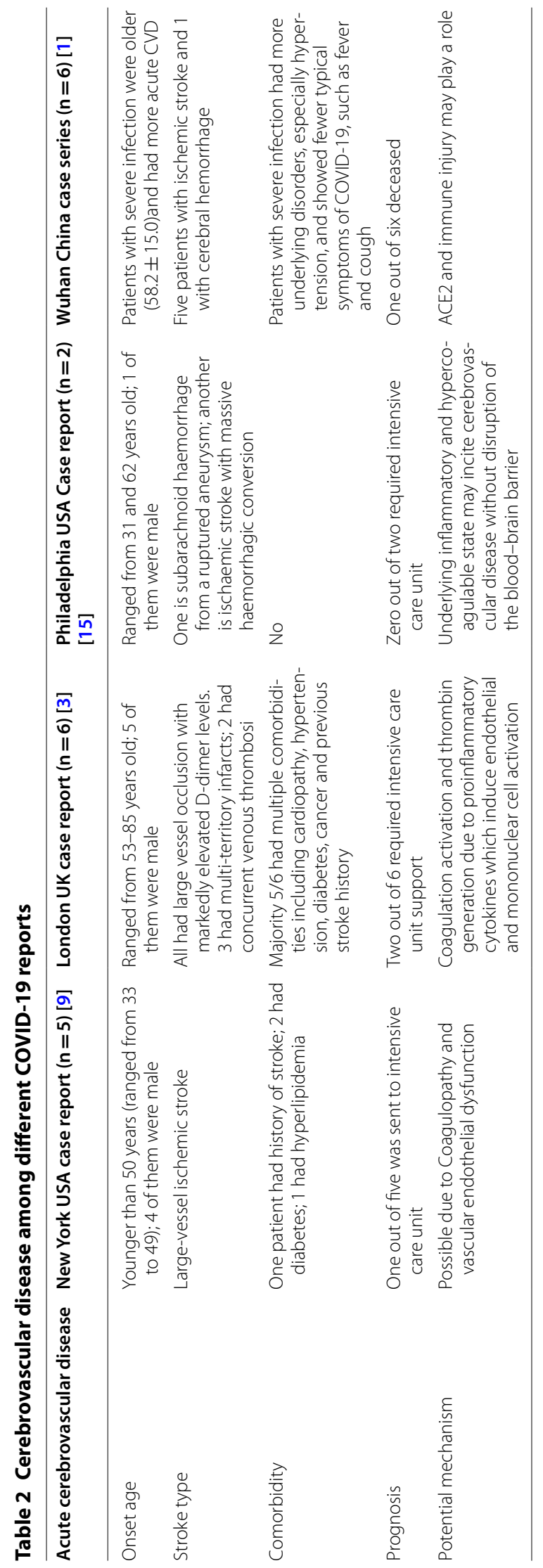




\section{Abbreviations}

COVID-19: Coronavirus disease 2019 infection; SARS: Severe Acute Respiratory Syndrome; H1N1: Influenza A virus subtype H1N1; CVD: Cerebrovascular diseases.

\section{Acknowledgements}

The authors thank the National Medical Research Council (STaR Award and Translational Clinical Research Programme in PD).

\section{Authors' contributions}

E-KT and XD: study concept and design; E-KT and XD drafting the manuscript; E-KT and Y-LL: revising the manuscript. All authors read and approved the final manuscript.

\section{Funding}

None.

\section{Availability of data and materials}

Not applicable.

Ethics approval and consent to participate

Not applicable.

\section{Consent for publication}

Not applicable.

\section{Competing interests}

No competing interests.

Received: 23 May 2020 Accepted: 27 November 2020

Published online: 09 December 2020

\section{References}

1. Mao L, Jin H, Wang M, et al. Neurologic manifestations of hospitalized patients with coronavirus disease 2019 in Wuhan China. JAMA Neurol. 2020. https://doi.org/10.1001/jamaneurol.2020.1127.

2. Umapathi T, Kor AC, Venketasubramanian N, et al. Large artery ischaemic stroke in severe acute respiratory syndrome (SARS). J Neurol. 2004;251(10):1227-31
3. Beyrouti $R$, Adams ME, Benjamin L, et al. Characteristics of ischaemic stroke associated with COVID-19. J NeurolNeurosurg Psychiatry. 2020. https://doi.org/10.1136/jnnp-2020-323586.

4. Asadi-Pooya AA, Yaghoubi E, Nikseresht A, Moghadami M, Honarvar B. The neurological manifestations of $\mathrm{H} 1 \mathrm{~N} 1$ influenza infection; diagnostic challenges and recommendations. Iran J Med Sci. 2011;36(1):36-9.

5. Tsai LK, Hsieh ST, Chao CC, et al. Neuromuscular disorders in severe acute respiratory syndrome. Arch Neurol. 2004;61(11):1669-73.

6. Lu L, Xiong W, Liu D, et al. New-onset acute symptomatic seizure and risk factors in Corona virus disease2019: a retrospective multicenter study. Epilepsia. 2020. https://doi.org/10.1111/epi.16524.

7. Kedia S, Stroud B, Parsons J, et al. Pediatric neurological complications of 2009 pandemic influenza A (H1N1). Arch Neurol. 2011;68(4):455-62.

8. Qiu H, Wu J, Hong L, Luo Y, Song Q, Chen D. Clinical and epidemiological features of 36 children with coronavirus disease 2019 (COVID-19) in Zhejiang, China: an observational cohort study. Lancet Infect Dis. 2020;20(6):689-96.

9. Oxley TJ, Mocco J, Majidi S, et al. Large-vessel stroke as a presenting feature of covid-19 in the young. N Engl J Med. 2020. https://doi. org/10.1056/NEJMc2009787.

10. Forman DE, Maurer MS, Boyd C, et al. Multimorbidity in older adults with cardiovascular disease. J Am CollCardiol. 2018;71(19):2149-61.

11. Li YC, Bai WZ, Hashikawa T. The neuroinvasive potential of SARS-CoV2 may play a role in the respiratory failure of COVID-19 patients. J Med Virol. 2020;92(6):552-5.

12. Ren $L$, Zhang W, Han $P$, et al. Influenza A virus (H1N1) triggers a hypoxic response by stabilizing hypoxia-inducible factor-1alpha via inhibition of proteasome. Virology. 2019;530:51-8.

13. Helms J, Kremer S, Merdji H, et al. Neurologic features in severe SARSCoV-2 infection. N Engl J Med. 2020;382(23):2268-70.

14. Ellul MA, Benjamin L, Singh B, et al. Neurological associations of COVID19. Lancet Neurol. 2020;19(9):767-83.

15. Al Saiegh F, Ghosh R, Leibold A, et al. Status of SARS-CoV-2 in cerebrospinal fluid of patients with COVID-19 and stroke. J NeurolNeurosurg Psychiatry. 2020. https://doi.org/10.1136/jnnp-2020-323522.

\section{Publisher's Note}

Springer Nature remains neutral with regard to jurisdictional claims in published maps and institutional affiliations.
Ready to submit your research? Choose BMC and benefit from:

- fast, convenient online submission

- thorough peer review by experienced researchers in your field

- rapid publication on acceptance

- support for research data, including large and complex data types

- gold Open Access which fosters wider collaboration and increased citations

- maximum visibility for your research: over $100 \mathrm{M}$ website views per year

At BMC, research is always in progress.

Learn more biomedcentral.com/submissions 